\title{
Profil minat belajar siswa dalam pembelajaran daring
}

\author{
Indah Rosyidah Sodik ${ }^{1)}$, Anna Rufaidah ${ }^{2 *}$, Susiati Susiati ${ }^{3)}$ \\ 1,2,3) Universitas Indraprasta PGRI \\ *) anna.rufaidah@unindra.ac.id
}

\begin{abstract}
Article History:
Received: 03/08/2021;

Revised: 19/10/2021;

Accepted: 22/10/2021

Published: 30/10/2021.
\end{abstract}

How to cite:

Sodik, I.R., Rufaidah, A., \& Susiati, S. (2021). Profil minat belajar siswa dalam

pembelajaran daring. Orien: Cakrawala Ilmiah Mahasiswa, 1(2), pp. 115-122. DOI:

10.30998/ocim.v1i2.6056

(c) (i) This is an open distributed under the Creative Commons 4.0 Attribution License, which permits unrestricted use, distribution, and reproduction in any medium, provided the original work is properly cited. (C) 2021, Sodik, Rufaidah, \& Susiati.

\begin{abstract}
Abstrak: Tujuan penelitian ini adalah untuk mengetahui profil minat belajar siswa dalam pembelajaran daring selama pandemi dan implikasinya dalam layanan bimbingan dan konseling di SMA Islam As-Syafi'iyah 01. Pendekatan yang digunakan dalam penelitian ini adalah pendekatan kuantitatif deksriptif. Sampel penelitian menggunakan teknik Purposive Sampling, yakni sejumlah 105 siswa kelas XI SMA Islam As-Syafi'iyah. Penelitian ini dilakukan dengan menyebarkan instrumen berupa kuesioner minat belajar dalam pembalajaran daring. Analisis data penelitian menggunakan statistik deskriptif. Hasil penelitian mengenai profil minat belajar menunjukkan bahwa minat belajar dalam pembelajaran daring di SMA Islam As-Syafi'iyah berada pada kategori sedang yaitu sebesar $84 \%$.
\end{abstract}

Kata Kunci: minat belajar, pembelajaran daring

\begin{abstract}
The aimed of this study was to determine the profile of students' interest in learning in online learning during the pandemic and its implications for guidance and counseling services at SMA Islam As-Syafi'iyah 01. The approach used in this study was a descriptive quantitative approach. The research sample used the purposive sampling technique, which was 105 students of class XI SMA Islam AsSyafi'iyah. This research was conducted by distributing an instrument in the form of a learning interest questionnaire in online learning. Analysis of research data using descriptive statistics. The results of the study regarding the profile of learning interest indicate that interest in learning in online learning at SMA Islam AsSyafi'iyah is in the medium category, which is $84 \%$.
\end{abstract}

Keywords: learning interest, online learning

\section{Pendahuluan}

Pandemi Covid-19 memaksa masyarakat dunia mendefinisikan makna hidup, tujuan pembelajaran dan hakikat kemanusiaan. Jika selama ini manusia-manusia dipaksa hidup dalam situasi serba cepat, pekerjaan tanpa henti, dan kejaran target pertumbuhan ekonomi dalam sistem kompetisi (Suharwoto, 2020). Menurut Suharwoto (2020) persebaran virus Corona (Covid19) yang menjadi krisis besar manusia modern, memaksa kita untuk sejenak bernafas, berhenti dari pusaran sistem, serta melihat kembali kehidupan, keluarga, dan lingkungan sosial dalam arti yang sebenarnya, manusia dipaksa 'berhenti' dari rutinitasnya, untuk memaknai apa yang sebenarnya dicari dari kehidupan.Covid-19 adalah penyakit menular yang disebabkan oleh jenis coronavirus yang baru ditemukan. Walaupun lebih banyak menyerang ke lansia, virus ini sebenarnya bisa juga menyerang siapa saja, mulai dari bayi, anak-anak, hingga orang dewasa. Virus corona ini bisa menyebabkan ganguan ringan pada sistem pernapasan, infeksi paru-paru yang berat, hingga kematian. Corona Virus Disease 2019 (COVID-19) pertama kali ditemukan di kota Wuhan, China pada akhir Desember 2019. Virus ini menular sangat cepat dan telah 
menyebar hampir ke semua negara, termasuk Indonesia, hanya dalam waktu beberapa bulan saja. Sehingga WHO pada tanggal 11 Maret 2020 menetapkan wabah ini sebagai pandemi global (Harnani, 2020). Hal tersebut membuat beberapa negara menetapkan kebijakan untuk memberlakukan lockdown dalam rangka mencegah penyebaran virus corona. Di Indonesia sendiri, diberlakukan kebijakan Pembatasan Sosial Berskala Besar (PSBB) untuk menekan penyebaran virus ini.Karena Indonesia sedang melakukan PSBB, maka semua kegiatan yang dilakukan di luar rumah harus dihentikan sampai pandemi ini mereda (Harnani, 2020).

Pandemi COVID-19 merupakan musibah yang memilukan bagi seluruh penduduk bumi. Seluruh kehidupan manusia di bumi terganggu, tanpa kecuali pendidikan. Banyak negara memutuskan menutup sekolah, perguruan tinggi maupun universitas, termasuk negara Indonesia (Syah, 2020). Menanggapi penyebaran virus corona yang tidak kunjung berkurang, pada tanggal 17 Maret 2020 Menteri Pendidikan dan Kebudayaan Republik Indonesia Nadiem Makarim mengeluarkan Surat Edaran Nomor 4 Tahun 2020 yang menjelaskan bahwa proses belajar dilaksanakan di rumah melalui pembelajaran daring/jarak jauh untuk memberikan pengalaman belajar yang bermakna bagi pesera didik (Rambe, n.d.) Konsekuensi dari penutupan Lembaga Pendidikan secara fisik dan mengganti dengan belajar di/dari rumah sebagaimana kebijakan pemerintah adalah adanya perubahan sistem belajar mengajar. Pengelola sekolah, siswa, orangtua, dan tentu saja guru harus bermigrasi ke sistem pembelajaran digital atau online, yang lebih dikenal dengan istilah e-learning atau dikenal dengan istilah pembelajaran dalam jaringan atau "pembelajaran daring" di Indonesia (Yunitasari \& Hanifah, 2020). Semua negara terdampak telah berupaya membuat kebijakan terbaiknya dalam menjaga kelanggengan layanan pendidkan. Indonesia juga menghadapi beberapa tantangan nyata yang harus segera dicarikan solusinya: (1) ketimpangan teknologi antara sekolah di kota besar dan daerah, (2) keterbatasan kompetensi guru dalam pemanfaatan aplikasi pembelajaran, (3) keterbatasan sumberdaya untuk pemanfaatan teknologi Pendidikan seperti internet dan kuota, (4) relasi guru-murid-orang tua dalam pembelajaran daring yang belum integral (Suharwoto, 2020).

Belajar merupakan kebutuhan bagi semua orang dan memiliki definisi yang sangat luas. Belajar merupakan suatu proses usaha yang dilakukan individu secara sadar untuk memperoleh perubahan tingkah laku tertentu, baik yang dapat diamati secara langsung sebagai pengalaman (latihan) dalam interaksi dengan lingkungan (Dalimunthe et al., 2020). Suatu proses belajar mengajar akan berjalan dengan lancar jika disertai dengan minat belajar dari diri siswa. Oleh karena itu, guru sebagai seorang pendidik harus memiliki suatu strategi dalam mengajar yang dapat membangkitkan serta meningkatkan minat siswa terhadap pelajarannya. Karena tanpa adanya minat belajar terhadap pelajaran yang diajarkan oleh guru, maka siswa akan menjadi malas dalam belajar dan proses pembelajaran yang diberikan oleh guru akan menjadi kurang optimal. Minat belajar adalah suatu rasa untuk menyukai atau juga tertarik pada suatu hal dan aktivitas belajar tanpa ada yang menyuruh untuk belajar (Ricardo \& Meilani, 2017). Minat belajar juga merupakan faktor pendorong untuk siswa dalam belajar yang didasari atas ketertarikan atau juga rasa senang keinginan iswa itu untuk belajar (Yunitasari \& Hanifah, 2020).

Tentunya dalam hal ini banyak sekali tantangan yang harus dihadapi oleh guru, siswa dan juga orang tua. Pembelajaran secara daring ini banyak mengundang keresahan dan banyak menimbulkan masalah baru. Permasalahan yang terjadi seperti kuota internet yang tidak mencukupi, jaringan yang tidak memadai, dan gawai yang tidak mendukung. Disamping itu para guru sebagai pendidik pun mengalami kesulitan yang serupa dengan pelajar. Masalah jaringan, kurangnya pelatihan, dan kurangnya kesadaran dinyatakan sebagai tantangan utama 
yang dihadapi oleh pengajar. Kurangnya kesadaran dinyatakan sebagai alasan paling penting oleh mereka yang tidak mengadopsi pembelajaran daring diikuti oleh kurangnya minat dan keraguan tentang kegunaan pembelajaran daring. Kurang kehadiran, kurangnya sentuhan pribadi, dan kurangnya interaksi karena masalah konektivitas ditemukan menjadi kelemaham signifikan dari pembelajaran daring (Arora \& Srinivasan, 2020). Siswa dan guru memerlukan adaptasi dalam menggunakan media teknologi dan media pembelajaran tersebut. Hal ini membuat guru dan siswa mengalami kesulitan dalam melaksanakan pembelajaran. Tidak adanya pengawasan dari guru secara langsung menyebabkan siswa menjadi kurang disiplin dalam melakukan kegiatannya. Sehingga hal ini mempengaruhi minat belajar siswa. Berdasarkan studi pendahuluan ditemukan bahwa pada awal pembelajaran daring, minat belajar siswa yang menurun terlihat pada saat kelas online berlangsung misalnya dengan mengerjakan atau melaksanakan pembelajaran untuk menggugurkan tugas yang diberikan oleh guru. Minimnya partisipasi didalam kelas online, cenderung pasif dan hanya sebatas kehadiran saja. Pada saat berlangsungnya layanan konferensi video seperti zoom meeting banyak dijumpai siswa yang hanya hadir tanpa mengaktifkan kamera, serta kelas yang pasif dan hanya beberapa siswa saja yang aktif di dalam kelas. Selain itu ada pula siswa yang selama pandemi covid-19 tidak hadir dalam pembelajaran karena berbagai hal, misalnya tidak memiliki handphone dan keterbatasan sinyal.

Penelitian ini bertujuan untuk mengetahui profil minat belajar siswa, sehingga guru dapat melakukan upaya-upaya untuk meningkatkan minat belajar siswa. Minat pada dasarnya merupakan perhatian yang bersifat khusus. Siswa yang menaruh minat pada suatu mata pelajaran, perhatiannya akan tinggi dan minatnya berfungsi sebagai pendorong kuat untuk terlibat secara aktif dalam kegiatan belajar mengajar.

Upaya untuk menjaga dan meningkatkan minat belajar juga menjadi perhatian dalam layanan bimbingan dan konseling di sekolah. Guru BK memiliki tugas yang sangat besar agar dapat membimbing dan mengarahkan siswa dalam menjalankan kegiatan belajar mengajar secara daring selama pandemi covid-19. Tentunya banyak sekali kendala yang dihadapi oleh siswa dalam menjalani kegiatan belajar. Hal ini juga menjadi tantangan bagi Guru BK dalam menghadapi berbagai permasalahan siswa terutama dalam hal minat belajar siswa dalam melaksanakan pembelajaran daring selama pandemi covid-19. Guru BK diharapkan dapat beradaptasi dan menyesuaikan dengan perkembangan teknologi yang ada agar dapat menampung semua permasalahan yang dialami siswa dan menentukan layanan yang sesuai dengan kebutuhan siswa saat pembelajaran daring berlangsung.

\section{Metode}

Pendekatan yang digunakan dalam penelitian ini adalah pendekatan kuantitatif deksriptif. Populasi terjangkau adalah seluruh siswa SMA Islam As-Syafi'iyah 01 kelas XI yang secara keseluruhan berjumlah 143 siswa. Sampel penelitian ditentukan dengan menggunakan teknik Purposive Sampling, yakni sejumlah 105 siswa kelas XI SMA Islam As-Syafi'iyah. Penelitian ini dilakukan dengan menyebarkan instrumen berupa kuesioner minat belajar dengan tipe skala likert. Penelitian dilaksanakan pada bulan Maret s/d bulan Juli 2021 selama pemberlakuan pembelajaran jarak jauh di masa Pandemi Covid-19. Teknik analisis data dilakukan dengan analisis statistik deskriptif untuk menggambarkan dan mendeskripsikan data dari variabel minat belajar siswa dalam pembelajaran daring. Untuk mengetahui kategorisasi 
tingkat minat belajar siswa dalam pembelajaran daring diperlukan mean teoretik dan satuan standar deviasi. Standar deviasi dihitung dengan cara mencari rentang skor, yaitu skor maksimal yang mungkin diperoleh responden dikurangi dengan skor minimal yang mungkin diperoleh responden, kemudian rentang skor tersebut dibagi enam (Azwar, 2012).

Data hasil penelitian diolah dengan menggunakan statistik deskriptif. Deskripsi data yang disajikan meliputi mean (M), median (Me) dan standar deviasi (SD). Mean merupakan ratarata hitung, modus adalah nilai dari data yang mempunyai frekuensi tertinggi atau nilai yang sering muncul dalam kelompok data sedangkan median yaitu nilai tengah dari gugusan data yang telah diurutkan (disusun) mulai dari data terkecil sampai data terbesar. Standar Deviasi (simpangan baku) adalah kelompok atau ukuran standar penyimpangan dari rata-ratanya.

\section{Hasil dan Diskusi}

Berdasarkan hasil penelitian maka dapat disajikan tabel distribusi frekuensi minat belajar siswa pada tabel berikut.

Tabel 1. Distribusi Frekuensi Minat Belajar Siswa

\begin{tabular}{cccc}
\hline No. & Interval & Frekuensi & $\mathbf{\%}$ \\
\hline 1. & $35-40$ & 2 & 2 \\
2. & $41-46$ & 8 & 8 \\
3. & $47-52$ & 17 & 16 \\
4. & $53-58$ & 26 & 25 \\
5. & $59-64$ & 32 & 30 \\
6. & $65-70$ & 14 & 13 \\
7. & $71-76$ & 5 & 5 \\
8. & $77-82$ & 1 & 1 \\
\hline & $\boldsymbol{\Sigma}$ & $\mathbf{1 0 5}$ & $\mathbf{1 0 0}$ \\
\hline
\end{tabular}

Berdasarkan tabel distribusi frekuensi variabel minat belajar di atas, dapat digambarkan dalam histogram sebagai berikut:

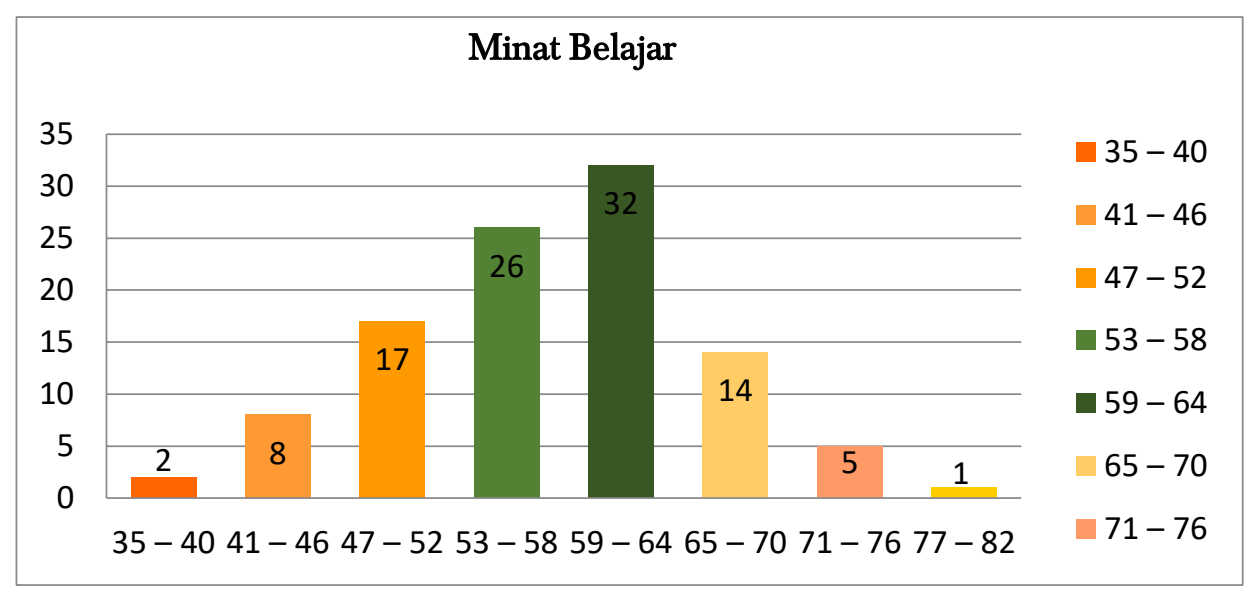

Gambar 1. Histogram Distribusi Frekuensi Minat Belajar

Tabel dan histogram tersebut, menunjukkan frekuensi variabel minat belajar paling banyak terletak pada interval 59-64 sebanyak 32 siswa (30\%) dan paling sedikit terletak pada interval 77-82 yaitu sebanyak 1 siswa (1\%). Berdasarkan perolehan data yang telah didapatkan dengan menggunakan instrumen berupa kuesioner minat belajar siswa dalam pembelajaran 
daring dalam penelitian ini, maka dilakukan analisis data dengan menggunakan statistik deskriptif yaitu berupa kuesioner minat belajar yang terdiri dari 22 item dengan 4 pilihan jawaban sehingga diperoleh hasil sebagai berikut :

$\begin{array}{ll}\text { Skor Maksimal Teoretik } & : 4 \times 22=88 \\ \text { Skor Minimal Teoretik } & : 1 \times 22=22 \\ \text { Luas jarak (Range) } & : 88-22=66 \\ \text { Mean Teoretik } & : 1 / 2(88+22)=55 \\ \text { Standar Deviasi } & : \frac{1}{6}(88-22)=11\end{array}$

Kategorisasi dan persentase disajikan dalam tabel 2 berikut.

Tabel 2. Kategorisasi Minat Belajar Siswa

\begin{tabular}{cccc}
\hline Kategori & Rentang Skor & Jumlah & Persentase \\
\hline Rendah & $<44$ & 5 & 5 \\
Sedang & $44-66$ & 88 & 84 \\
Tinggi & $>66$ & 12 & 11 \\
\hline & Total & $\mathbf{1 0 5}$ & $\mathbf{1 0 0}$ \\
\hline
\end{tabular}

Berdasarkan tabel 2 dapat digambarkan dalam pie chart di bawah ini:

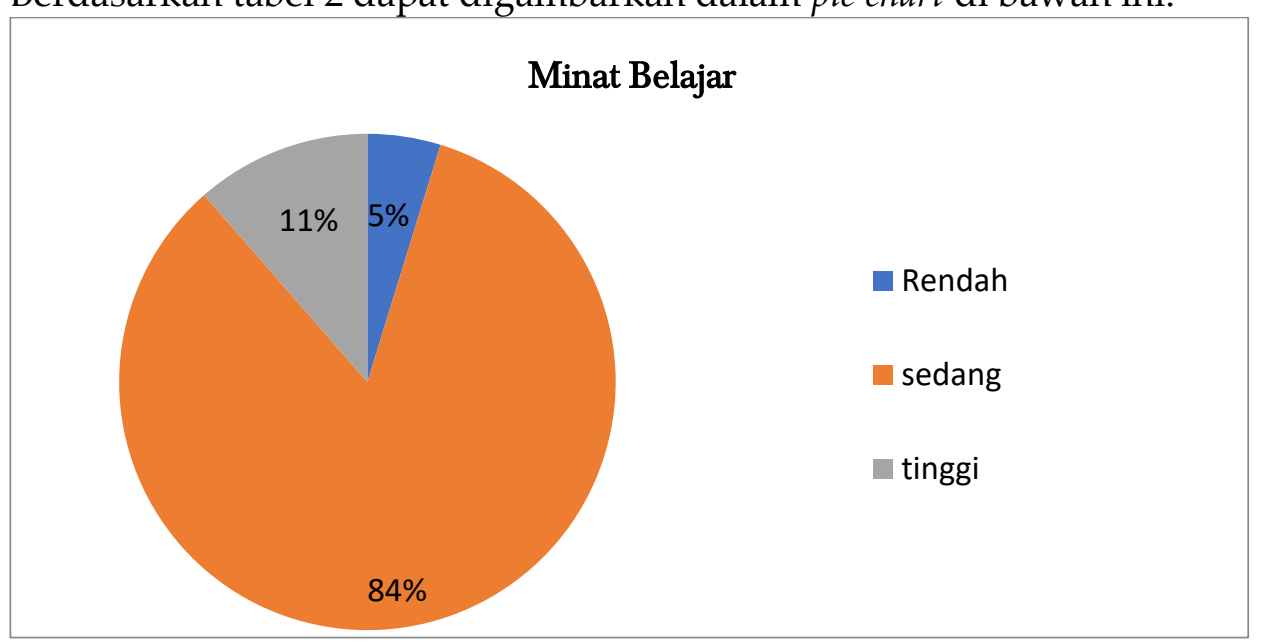

Gambar 2. Pie Chart Kategori Minat Belajar Siswa

Tabel dan piechart di atas menunjukkan bahwa siswa kelas XI SMA Islam As-Syafi'iyah memiliki minat belajar dalam pembelajaran daring yang dihitung dari sejumlah sampel sebanyak 105 siswa. Siswa yang memiliki kategori tinggi sebanyak 12 siswa atau sebesar 11\%, minat belajar dalam pembelajaran daring kategori sedang 88 siswa atau sebesar $84 \%$ dan kategori rendah sebanyak 5 siswa atau sebesar $5 \%$. Jadi dapat disimpulkan bahwa, kecenderungan minat belajar dalam pembelajaran daring siswa berada pada kategori sedang yaitu sebanyak 88 siswa atau sebesar $84 \%$ dari jumlah sampel yang berjumlah 105 peserta.

Minat belajar adalah salah satu faktor yang sangat penting untuk keberhasilan belajar yang dimiliki siswa, minat muncul dari dalam diri siswa itu sendiri. Faktor dari luar minat belajar yaitu bagaimana cara guru tersebut mengajar. Peran guru sangat penting untuk menumbuhkan minat belajar siswa salah satu dengan cara mengajar yang menyenangkan, memberikan motivasi yang membangun (Iqbal et al., 2021). Dalam hal ini siswa kelas XI SMA Islam As-Syafi'iyah memiliki minat belajar dalam pembelajaran daring di masa pandemi covid-19. Pandemi covid- 
19 membuat kegiatan pembelajaran yang biasanya dilakukan di sekolah berubah menjadi pembelajaran di rumah secara daring. Hal ini tentunya akan mempengaruhi siswa dalam melakukan proses belajar, perlunya adaptasi dengan suasana baru kemudian harus berhadapan dengan beberapa kendala yang mungkin saja terjadi seperti jaringan internet yang tidak memadai serta kurangnya fasilitas belajar di rumah. Pembelajaran daring di sekolah masih ditemukan banyak terjadi. Permasalahan ini dialami oleh siswa, orang tua siswa, dan juga guru, yang diantaranya berkaitan dengan kurangnya pengetahuan tentang teknologi informasi oleh siswa mapun orang tua siswa, pembelajaran menjadi membosankan dan penilaian pembelajaran yang seharusnya bisa dilakukan secara langsung jadi tidak bisa dilakukan (Prawanti \& Sumarni, 2020).

Adapun faktor-faktor yang dapat mempengaruhi minat belajar menurut Suryabrata dalam Syahputra (2020) dibagi menjadi dua yaitu:

1) Faktor Internal

Faktor internal adalah sesuatu yang membuat pelajar berminat, yang berasal dari dalam diri sendiri. Faktor internal tersebut antara lain: pemusatan perhatian, keingintahuan, dan motivasi.

a) Perhatian dalam belajar yaitu pemusatan atau konsentrasi

b) Keingintahuan adalah perasaan atau sikap yang kuat untuk mengetahui sesuatu atau dorongan kuat untuk mengetahui lebih banyak tentang sesuatu. Semakin besar keingintahuan seseorang menunjukkan semakin tinggi minat orang tersebut.

c) Motivasi adalah perubahan energi dalam diri seseorang yang ditandai dengan timbulnya perasaan dan reaksi untuk mencapai tujuan.

2) Faktor Eksternal

Faktor eksternal adalah sesuatu yang membuat siswa berminat yang datangnya dari luar diri, seperti: dorongan dari orang tua, dorongan dari pendidik, tersedianya sarana dan prasarana atau fasilitas dan keadaan lingkungan.

Menurut (Ru'iya et al., 2021) perlu dilakukan pendampingan terhadap siswa untuk tetap konsisten dan disiplin menjaga kesehatan dan mengajak untuk terus giat belajar walaupun melalui belajar online dari rumah masing-masing. Beberapa upaya yang dapat dilakukan untuk dapat menjaga dan meningkatkan minat belajar selama pandemi adalah dengan menggunakan media pembelajaran yang menarik, misalnya dengan media komik (Ru'iya et al., 2021) atau dengan game edukatif (Hartati et al., 2020). Bertemu hanya melalui layar zoom meeting, google meet, whatsapp atau platform digital lainnya menyebabkan siswa kurang merasakan keterlibatan guru dalam proses KBM yang dijalani (pintek.id, 2020). Beberapa cara kreatif dapat dilakukan oleh guru untuk meningkatkan minat belajar siswa yaitu dengan: metode hibur, menggunakan aplikasi kreatif, dan membuat rencana pembelajaran yang melibatkan siswa (pintek.id, 2020).

\section{Implikasi dalam Layanan Bimbingan dan Konseling}

Masa pandemi covid-19 membuat proses pembelajaran yang dilakukan secara tatap muka antara guru dan siswa menjadi terhenti dan digantikan oleh pembelajaran di rumah yang dilakukan secara daring. Dalam hal ini minat belajar sangat penting bagi siswa agar mereka dapat tetap memperoleh pendidikan, mengembangkan potensi dan meningkatkan keterampilan diri. Melihat profil minat belajar berdasarkan hasil penelitian, maka ada beberapa implikasi yang 
dapat dilakukan oleh Guru Bimbingan dan Konseling di sekolah yaitu dengan cara sebagai berikut:

1. Layanan informasi yaitu pemberian layanan berupa penyampaian informasi oleh Guru BK kepada siswa dikelas atau secara individual. Pemberian informasi yang diberikan dilakukan secara daring menggunakan media teknologi informasi serta dikemas secara menarik. Informasi yang diberikan berkaitan dengan proses belajar yang dilakukan siswa yang ditujukan untuk meningkatkan minat belajar siswa dalam pembelajaran daring.

2. Layanan Konseling Perorangan yaitu pemberian layanan kepada klien secara individu oleh Guru BK guna mengentaskan masalah yang dialami oleh klien. Layanan ini diberikan apabila terdapat siswa yang memiliki masalah atau kesulitan dalam hal belajar daring di rumah sehingga mengganggu kehidupan efektif sehari-hari. Layanan ini tentunya dilakukan secara daring melalui media komunikasi antara guru dengan siswa.

3. Layanan Bimbingan Kelompok yaitu layanan bimbingan yang memungkinkan sejumlah siswa secara bersama-sama memperoleh berbagai bahan dari narasumber tertentu (terutama dari pembimbing konselor) yang berguna untuk menunjang kehidupannya sehari-hari baik individu maupun sebagai pelajar, anggota keluarga dan masyarakat, serta untuk pertimbangan dalam pengambilan keputusan. Dalam pembelajaran daring selama pandemi dapat dilakukan dengan mengadakan pertemuan melalui video conference.

4. Memanfaatkan kegiatan pendukung berupa kunjungan rumah (KRU) sebagai upaya untuk mendeteksi kondisi keluarga dalam kaitannya dengan permasalahan siswa terkait minat belajar siswa dengan persetujuan sekolah dan orang tua serta dengan menerapkan protokol kesehatan pada masa pandemi. Dengan KRU akan diperoleh berbagai informasi atau data yang dapat digunakan untuk lebih mengefektifkan layanan konseling dalam mengentaskan permasalahan siswa.

\section{Simpulan}

Berdasarkan hasil penelitian yang telah diteliti pada siswa kelas di SMA Islam AsSyafi'iyah 01 tentang profil minat belajar siswa dalam pembelajaran daring selama pandemi dan implikasinya dalam layanan bimbingan dan konseling di SMA Islam As-Syafi'iyah 01, diperoleh simpulan bahwa profil minat belajar siswa dalam pembelajaran dari di SMA Islam As-Syafi'iyah cenderung berada pada tingkat kategori sedang yaitu sebesar $84 \%$. Beberapa upaya dapat dilakukan oleh guru sebagai upaya untuk meningkatkan minat belajar dengan memanfaatkan aplikasi yang kreatif dan media pembelajaran yang menarik. Penelitian ini juga memberikan implikasi dalam pelayanan BK di sekolah. Optimalisasi layanan BK terhadap siswa akan dapat mengembangkan serta meningkatkan minat belajar dalam pembelajaran daring, dengan begitu siswa dapat terus melakukan pembelajaran daring di rumah selama pandemi.

\section{Ucapan Terima Kasih}

Penelitian ini tentunya tidak akan berjalan dengan lancar tanpa adanya bantuan dari berbagai pihak. Ucapan terima kasih dan rasa hormat kepada semua pihak yang dengan tulus ikhlas telah memberikan bantuan dan dorongan selama pelaksaan penelitian. Untuk keluarga dan sahabat yang selalu memotivasi serta pihak sekolah yang memberikan izin dalam kegiatan penelitian. 


\section{Daftar Rujukan}

Azwar, S. (2014). Penyusunan Skala Psikologi. Edisi 2. Yogyakarta: Pustaka Belajar.

Arora, A. K., \& Srinivasan, R. (2020). Impact of pandemic COVID-19 on the teaching - learning process: A study of higher education teachers. Prabadhan: Indian Journal of Management, 13(4). https://doi.org/10.17010/pijom/2020/v13i4/151825

Dalimunthe, R., Harahap, R., \& Harahap, D. (2020). Analisis Minat Belajar Siswa Sekolah Dasar Terhadap Mata Pelajaran IPA Pada Masa Pandemi Covid-19. Jurnal Basicedu, 3(2), 524-532.

Harnani, S. (2020). Efektivitas Pembelajaran Daring Di Masa Pandemi Covid-19. Akses BDK Jakarta Kementrian Agama RI. Diakses dari : https://bdkjakarta.kemenag.go.id/beritalefektivitaspembelajaran-daring-di-masa-pandemi-covid-19

Hartati, S., Fatmawati, L., \& Krismilah, T. (2020). Upaya Meningkatkan Minat Dan Hasil Belajar Siswa Dengan Game Edukatif Pada Pembelajaran Tematik Muatan Ipa Kelas V Sd Masjid Syuhada. Artikel Mahasiswa, 45-56. http://eprints.uad.ac.id/id/eprint/21207\%0A

Iqbal, M., Hari, I. B., Bulian, M., Hari, I. B., Bulian, M., Mardhotillah, P., Hari, I. B., Bulian, M., Ayu, S., Hari, I. B., Bulian, M., Hari, I. B., Bulian, M., Sari, U., Hari, I. B., \& Bulian, M. (2021). Pengaruh Pembelajaran Daring Terhadap Minat Belajar Siswa di Madrasah Ibtidiyah ( MI ). 3(1), $81-90$.

Pintek (2020, November 12). Cara Meningkatkan Minat Belajar Siswa di Musim Pandemi. Retrieved from https://pintek.id/blog/minat-belajar-siswal

Pusdatin Kemdikbud. (2020). Pembelajaran Online di Tengah Pandemi Covid-19, Tantangan yang Mendewasakan. Diakses 21 Oktober 2021 dari :https://pusdatin.kemdikbud.go.id/pembelajaranonline-di-tengah-pandemi-covid-19-tantangan-yang-mendewasakan/

Rambe, C. N. (n.d.). Strategi Pembelajaran Melalui Daring Dan Luring Dalam Masa Pandemi Covid19 Di Sekolah.

Ricardo, R., \& Meilani, R. I. (2017). Impak Minat dan Motivasi Belajar Terhadap Hasil Belajar $\begin{array}{lllll}\text { Siswa. Jurnal Pendidikan } & \end{array}$ https://doi.org/10.17509/jpm.v2i2.8108

Prawanti, L. T., \& Sumarni, W. (2020). Kendala Pembelajaran Daring Selama Pandemic Covid-19. Prosiding Seminar Nasional Pascasarjana UNNES, 286-291.

Sugiyono. (2012). Metode Penelitian Pendidikan. Bandung: Alfabeta

Syahputra, E. Snowball Throwing Tingkatan Minat dan Hasil Belajar. Sukabumi: Haura Publishing.

Syah, R. H. (2020). Dampak Covid-19 pada Pendidikan di Indonesia: Sekolah, Keterampilan, dan Proses Pembelajaran. SALAM: Jurnal Sosial Dan Budaya Syar-I, 7(5). https://doi.org/10.15408/sjsbs.v7i5.15314

Ru'iya, S., Kistoro, H. C. A., Sutarman, S., \& ... (2021). Meningkatkan minat belajar siswa di masa pandemi Covid-19 melalui media komik. Community ..., 6(6), 1021-1028. http://journal.unimma.ac.id/index.php/ce/article/view/4914

Yunitasari, R., \& Hanifah, U. (2020). Pengaruh Pembelajaran Daring terhadap Minat Belajar Siswa pada Masa COVID 19. Edukatif: Jurnal Ilmu Pendidikan, 2(3), 232-243. https://doi.org/10.31004/edukatif.v2i3.142

\section{Competing interests:}

The authors declare that they have no significant competing financial, professional or personal interests that might have influenced the performance or presentation of the work described in this manuscript. 